Report

\title{
Epidemic of cutaneous leishmaniasis: 109 cases in a population of $\mathbf{5 0 0}$

\author{
M. Anwar, ${ }^{1}$ M.A. Hussain, ${ }^{1}$ H. Ur-Rehman, ${ }^{2}$ I. Khan ${ }^{1}$ and R.A. Sheikh ${ }^{1}$
}

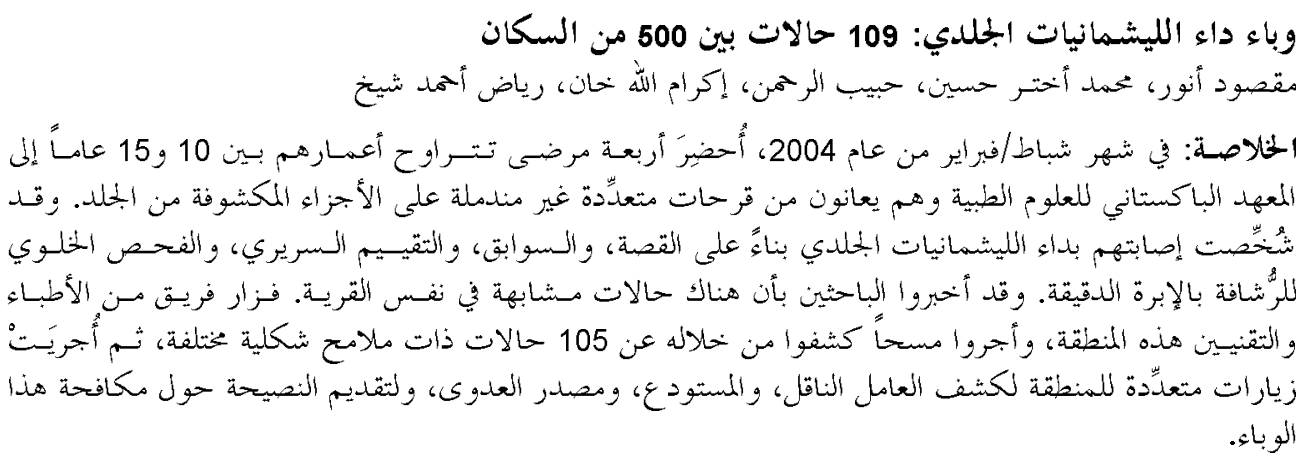

ABSTRACT In February 2004, 4 patients aged 10-15 years presented at the Pakistan Institute of Medical Sciences with non-healing multiple ulcers on exposed parts. On the basis of history, clinical assessment and fine needle aspiration cytology, they were diagnosed as having cutaneous leishmaniasis. We were informed that several similar cases were present in their village. A team of doctors and technicians visited the area. A survey was conducted and another 105 cases with various morphological presentations were identified. The area was visited several times to find the vector, reservoirs and source of infection and to advise on controlling the epidemic.

Épidémie de leishmaniose cutanée : 109 cas dans une population de 500 individus RÉSUMÉ En février 2004, 4 patients âgés de 10 à 15 ans se sont présentés à l'Institut pakistanais des Sciences médicales avec des ulcères multiples ne cicatrisant pas sur les parties découvertes du corps. Le diagnostic de leishmaniose cutanée a été posé sur la base de l'anamnèse, de l'évaluation clinique et de la cytoponction à l'aiguille fine. Nous avons été informés de la présence dans leur village d'origine de plusieurs cas similaires. Une équipe de médecins et de techniciens s'est rendue dans la région. L'enquête menée alors a permis d'identifier 105 autres cas avec diverses manifestations morphologiques. La région a été visitée à plusieurs reprises à la recherche du vecteur, des réservoirs et de la source d'infection et pour prodiguer à la population les conseils permettant de juguler l'épidémie.

${ }^{1}$ Department of Dermatology, Pakistan Institute of Medical Sciences, Islamabad, Pakistan (Correspondence to M. Anwar: maqsoodanwar99@yahoo.com).

${ }^{2}$ Department of Dermatology, Islamic International Medical College, Rawalpindi, Pakistan.

Received: 24/04/05; accepted: 11/09/05 


\section{Introduction}

Leishmaniasis, a protozoan disease endemic in many subtropical countries around the world, has gained increasing importance because of the AIDS epidemic and expanded international travel [1]. Coinfection with AIDS and leishmaniasis produces a cumulative deficiency of the immune response system: Leishmania parasites and HIV destroy the same cells, resulting in an exponential increase in disease severity and consequences.

The disease is endemic in 88 countries on 4 continents. More than $90 \%$ of cutaneous leishmaniasis cases occur in Afghanistan, Brazil, Islamic Republic of Iran, Peru, Saudi Arabia and the Syrian Arab Republic. Humans are infected via the bite of sandflies (subfamily Phlebotominae), tiny, sandcoloured, blood-feeding flies that breed in forest areas, caves or the burrows of small rodents. Wild and domesticated animals and humans themselves can act as reservoirs of infection [2].

Cutaneous leishmaniasis can produce large numbers of skin ulcers - as many as 200 in some cases - on the exposed parts of the body, such as the face, arms and legs, causing serious disability and leaving the patient permanently scarred [3].

In Pakistan, the most common manifestation of infection is cutaneous leishmaniasis. It is endemic in many parts of the country, while sporadic cases are seen throughout the country [4].

The World Health Organization recently sponsored a rapid survey in Kurram Agency in North-West Frontier Province and found 289 cured cases as well as the 738 new cases; in most cases, the disease had been contracted in the previous 6 months [5].

The purpose of this report is to draw the attention of both local health providers and international agencies to the rapidly and massively emerging epidemics of cutaneous leishmaniasis in previously non-endemic areas of Pakistan and neighbouring countries. The vector is already present in most parts, therefore, wherever the agent arrives, the disease appears as epidemic.

The outbreak described in this report, 109 cases in a population of 500, is an example. This situation will create a social and economic burden on the country as well as the World Health Organization.

\section{Discovery of the epidemic}

\section{First four cases}

In February 2004, 4 patients aged 10-15 years came to the Department of Dermatology, Pakistan Institute of Medical Sciences in Islamabad along with the doctor in charge of the rural health centre in their village, Dhoke Awan. They presented with non-healing multiple ulcers, with raised margins and central necrosis, on their exposed parts.

On the basis of history, clinical assessment and fine needle aspiration cytology, they were diagnosed as having cutaneous leishmaniasis. At that time we were informed that several similar cases were present in the village. We decided to visit the area as soon as possible.

The objectives of our visit were to carry out a biological survey of the area; to determine the environmental conditions; to identify cases and start their treatment; and to provide awareness about control and prevention of the disease to the local health workers and population.

\section{Survey of village}

The epidemic area is a beautiful village located about $35 \mathrm{~km}$ from the LahoreIslamabad motorway in the Vanhar valley, Khushab district.

The population of the village is about 500. Most of the houses are constructed us- 
ing bricks and rocks (solid material); a few are mud houses or temporary shelters. In some large houses the yards also house the domestic animals. This type of environment and type of construction supports the population of rodents and sandflies (reservoir and vector); increases in their population can increase the chances of infection in humans.

There was no proper disposal of garbage and waste. The population was of poor socioeconomic status: most of the villagers were either labourers working in the coal mines adjacent to their village or farmers.

During our survey of the village, we did not find any sandflies. They had probably been eradicated due to the insecticide spraying which had been done a couple of days prior to our visit; we later captured a few sandflies in the adjacent village.

\section{Work plan}

We designed our work plan according to the situation and the available resources and made up 3 teams. The first team comprised 2 doctors; they were assigned to do the clinical assessment and diagnosis, to prescribe medicine to the individual patients and to record the information on a data collection form. The second team had 1 doctor and 3-4 paramedics to provide the treatment. The third team comprised young volunteers from the village; they were assigned to make announcements, to encourage patients to attend the clinic for treatment and to find new suspects and notify the doctors on the first team.

\section{Identification and enrolment of cases}

On the first visit 109 cases, including those who came to the hospital, were identified and enrolled on the treatment register. We treated 96 of them, 13 patients refused treat- ment owing to a fear of injections. They came back later after being encouraged by the volunteers.

\section{Diagnosis/treatment in the epidemic area}

Diagnosis in the first 4 cases had been confirmed on fine needle aspiration cytology performed in the Department of Pathology, Pakistan Institute of Medical Sciences, Islamabad, and they were considered a subset of the general population.

In the endemic area, diagnosis was based on history and clinical assessment only. Patients were treated with intra-lesional injection of Glucantime, systemic antibiotic and topical creams where there was secondary bacterial infection. Dosage of Glucantime depended on the number of lesions, but did not exceed the intramuscular dose. Patients were followed up for 12 weeks.

\section{Prevention and control}

For prevention and control, the following suggestions were given to the local health authorities through the medical officer in charge of the rural health centre.

- Control of vectors by insecticide spray;

- control of the parasite with an expanded and immediate treatment plan of all infected persons;

- control of reservoirs, e.g. destruction of rodents and their burrows, identification of other mammal reservoirs;

- protection of people from infection with the use of mosquito nets and insect repellents;

- proper disposal of garbage.

\section{Discussion}

Cutaneous leishmaniasis has been reported from Multan, Lahore, Dera Ghazi Khan, Dera Ismail Khan, Chakwal, Talagang, 
Rawalpindi and Attock, all in Punjab. Sporadic cases are also found in North-West Frontier Province, Azad Jammu and Kashmir, Northern Areas and the federal capital, Islamabad [6].

The whole Vanhar valley was considered non-endemic for cutaneous leishmaniasis: doctors and other health workers were not aware of the disease. Over a very short period of time, multiple epidemics have emerged in this area.

We believe that the vector was present in this area as a normal habitat (as in other barren areas, arid lands and forests of $\mathrm{Pa}$ kistan) but the agent arrived later with the migration of people from endemic areas, in particular Afghan refugee labourers. The results were disastrous.

Recent war-related population movements and environmental destruction have caused a large increase in the prevalence of cutaneous leishmaniasis in the tribal belt bordering Afghanistan. The disease spread to refugee camps in tribal areas of Pakistan and is now transmitted locally in those areas [7].

The patients had all received treatment of various types, including topical and sys- temic antibiotics, steroids and home-made remedies, but they had little effect. The steroids and home made remedies resulted in disseminated lesions. Poor hygiene and malnutrition played a major role in the occurrence of secondary bacterial infection: one little girl with ectodermal dysplasia had more than 50 lesions on her face and upper and lower limbs.

\section{Acknowledgements}

Our thanks go to Professor S. Fazle Hadi, Pakistan Institute of Medical Science, Dr Mirza Azkar Ahmed, Professor Anwarul Haque and Dr Shugufta of the Pathology Department. Thanks also to the staff of the Department of Dermatology and the Department of Pathology, Pakistan Institute of Medical Sciences.

We are also grateful to Dr Nisar Ahmed and the staff of the rural health centre, Padhrar, and the health authorities in Khushab district. Special thanks to Malik Javed Iqbal, Member Provincial Assembly, Khushab, for logistic support.

\section{References}

1. Lee MB, Gilbert HM. Current approaches to leishmaniasis. Infections in medicine, 1999, 16(1):37-45.

2. Leishmaniasis. Disease information. Geneva, World Health Organization, 2004, (www.who.int/tdr/diseases/leish/diseaseinfo.htm, accessed 20 December 2006).

3. The leishmaniases and Leishmania/HIV co-infections. Geneva, World Health Organization, 2000 (Factsheet No. 116) (www.who.int/mediacentre/factsheets/ fs116/en/print.html, accessed 20 December 2006).

4. Rahman SB, Bari AU. Laboratory profile in patients of $C L$ from various regions of
Pakistan. Journal of the College of Physicians and Surgeons-Pakistan, 2003, 13(6):313-6.

5. 2002-Leishmaniasis in Pakistan. Geneva, World Health Organization, 2002 (www.who.int/csr/don/2002_01_16/en/index.html, accessed 20 December 2006).

6. Bari AU, Rahman SB. A therapeutic update on cutaneous leishmaniasis. Journal of the College of Physicians and Surgeons-Pakistan, 2003, 13(8):471-8.

7. Noor SM, Khan MM, Hussain D. Intralesional chloroquin in cutaneous leishmaniasis. Journal of Pakistan Association of Dermatologists, 2005, 15(1):18-21. 